\title{
Development and characterization of a biodegradable polyphosphate
}

\author{
Michael L. Renier ${ }^{1,2}$ and David H. Kohn ${ }^{1,3, *}$ \\ ${ }^{1}$ Department of Biologic and Materials Sciences, School of Dentistry; ${ }^{2}$ College of Pharmacy; and ${ }^{3}$ Bioengineering \\ Program, University of Michigan, Ann Arbor, MI 48109-1078
}

A biodegradable polyphosphate polymer $\left(\mathrm{M}_{\mathrm{n}}=18,000, \mathrm{M}_{\mathrm{w}} /\right.$ $M_{n}=3.2$ ) matrix system was developed as a potential delivery vehicle for growth factors. As a model system, release of recombinant human osteogenic protein-1 (OP-1) from this polymer was evaluated. The polyphosphate was synthesized using a triethylamine catalyst in an argon environment, and characterized using elemental analysis, gel permeation chromatography (GPC), and Fourier transform infrared spectroscopy (FTIR). Degradation kinetics of the polyphosphate polymer in phosphate-buffered saline (PBS) were represented by a second-order polynomial while degradation in bovine serum was linear with time. The polymer degraded faster in PBS than in bovine serum. In vitro release of OP-1 was also faster in PBS than in serum. Release kinetics of OP-1 in PBS and serum were represented by second-order polynomials. The OP-1 release from this physically dispersed polymeric matrix may be described by several possible mechanisms: diffusion, bulk polymer degradation, ion complexation, and interactions among the protein (OP-1), polymer, proteins, and enzymes in the media. This polyphosphate may be an effective carrier for morphogens, growth factors, or other classes of bioactive molecules. (c) 1997 John Wiley \& Sons, Inc.

\section{INTRODUCTION}

To deliver biologically active molecules, such as polypeptide growth factors and morphogens, in a safe, controlled, and effective manner, and with an optimal response, requires a knowledge of the local and systemic biology as well as materials technology. Tissue formation may be triggered by seeding cells onto, or releasing biologically active molecules from, a degradable system of natural and/or synthetic materials. To increase the therapeutic potential of growth factors, there exists a need for local delivery to larger defect regions. Synthetic polymers may serve as temporary scaffolds for the migration, attachment, proliferation, and differentiation of progenitor cells in response to the incorporated biologically active molecules.

A variety of scaffold materials for bone repair has been introduced, including bovine collagen, ${ }^{1,2}$ demineralized bone matrix, ${ }^{3-5}$ fibrin, ${ }^{6}$ chitosan, ${ }^{7}$ calcium phosphate ceramics, ${ }^{6,8}$ plaster of Paris, ${ }^{9}$ bioglasses,${ }^{10,11}$ organoapatites, $^{12}$ polylactic acid (PLA) homopolymers, polylactic acid/polyglycolic acid (PLA/PGA) copolymers, ${ }^{13-16}$ polylactic acid/polyethylene glycol (PLA/

*To whom correspondence should be addressed.
PEG) copolymers, ${ }^{17}$ polyanhydrides, ${ }^{18}$ organophosphates, ${ }^{19,20}$ poly(orthoesters), ${ }_{2}^{21}$ polyphosphazenes, ${ }^{22}$ and pseudo-polyaminoacids. ${ }^{23}$

The most extensively studied system is PLA/PGA containing osteoconductive factors. ${ }^{13-16}$ There are indications that some PLA/PGA copolymers may cause an inflammatory foreign-body response and sterile abscess formation due either to release of crystallite degradation products or to a drop in local $\mathrm{pH}$ related to polymer degradation. ${ }^{24-26} \mathrm{~A}$ drop in local $\mathrm{pH}$ may arise from a reduced metabolic clearance and possible recruitment of osteoclasts to the repair site. This, in turn, can result in bone resorption and extracellular matrix degradation..$^{27,28}$

An ideal synthetic polymer for bone repair may be one with a phosphodiester backbone because the phosphate backbone, which is found in natural biopolymers, is prone to hydrolytic attack by biochemical enzymes, phospholipases, and phosphodiesterases. ${ }^{29}$ Additionally, compared to other polymers (e.g., PLA), phosphodiesters remain anionic over wider ranges of $\mathrm{pH}$, and when they hydrolyze, local $\mathrm{pH}$ is less susceptible to change. ${ }^{30}$

Recently the use of poly(phosphate) and poly(phosphazene) synthetic polymers for bone induction has grown in popularity. ${ }^{19,20,22}$ This increased use has arisen 
from the fact that it is possible to change the composition of the starting materials, which allows for variation in the degree of hydrophilicity or hydrophobicity of a given polymer. In general, a series of parent polyphosphates may be developed. Subsequent modifications of pendant side chains may be used to alter properties and ultimately to create classes of biomaterials with a continuum of properties. ${ }^{19,23}$

The objectives of this in vitro study were to: 1) synthesize a polyphosphate polymer and characterize this material and its degradation products in terms of elemental constituents, molecular weight, molecular weight distribution, and infrared spectra; 2) measure the hydrolytic stability and degradation kinetics of the polymer in phosphate-buffered saline (PBS) and fetal bovine serum (FBS); and 3) incorporate a candidate growth factor (recombinant human osteogenic protein1 , OP-1) into the polymer matrix and measure its release kinetics in PBS and FBS.

A polyphosphate polymer was prepared by a polycondensation of bisphenol A (BPA) and phenyl phosphodichloridate (PPDC). A candidate growth factor, OP-1, was incorporated into the polymer using a simple mixing procedure based on the solubility of the polyphosphate in acetone and OP-1 in acetonitrile and ethanol.

\section{MATERIALS AND METHODS}

\section{Polymer synthesis}

Synthesis of the poly(bisphenol A-phenylphosphate) $\left(\mathrm{M}_{\mathrm{n}}=18 \mathrm{kDa}, \mathrm{M}_{\mathrm{w}} / \mathrm{M}_{\mathrm{n}}=3.2\right)$ is shown schematically in Figure 1. The starting reagents, catalysts, solvents, and drying agents for the polyphosphate synthesis are shown in Table I. A 500-mL reaction vessel was continuously purged with argon at $1.5 \mathrm{~kg} / \mathrm{cm}^{2}$ throughout the reaction. The reaction was started by addition of a diol, bisphenol A (0.01 moles, $2.28 \mathrm{~g})$, to the reaction vessel. The diol was dissolved into $100 \mathrm{~mL}$ of highperformance liquid chromatography (HPLC) grade toluene. The reaction mixture was vigorously stirred using a mechanical stirrer. Triethylamine $(0.05 \mathrm{~g})$, an acid acceptor, was added to the mixture. After dissolution of the diol, phenyl-phosphodichloridate (0.01 moles, $2.11 \mathrm{~g}$ ) was slowly added to the reactant mixture over $30 \mathrm{~min}$. Evolution of $\mathrm{HCl}$ gas was recovered by the triethylamine catalyst forming a quaternary amine salt. The reaction was run at $70^{\circ} \mathrm{C}$ for $2 \mathrm{~h}$. After the reaction the polymer was dissolved in acetone and precipitated into hexane solution, both HPLC-grade solvents. The reaction yield for the polymer product was $3.95 \mathrm{~g}(90 \%)$, which was calculated based on weighing the product in relation to the total weight of the reactants. The polymer was then dried in vacuo

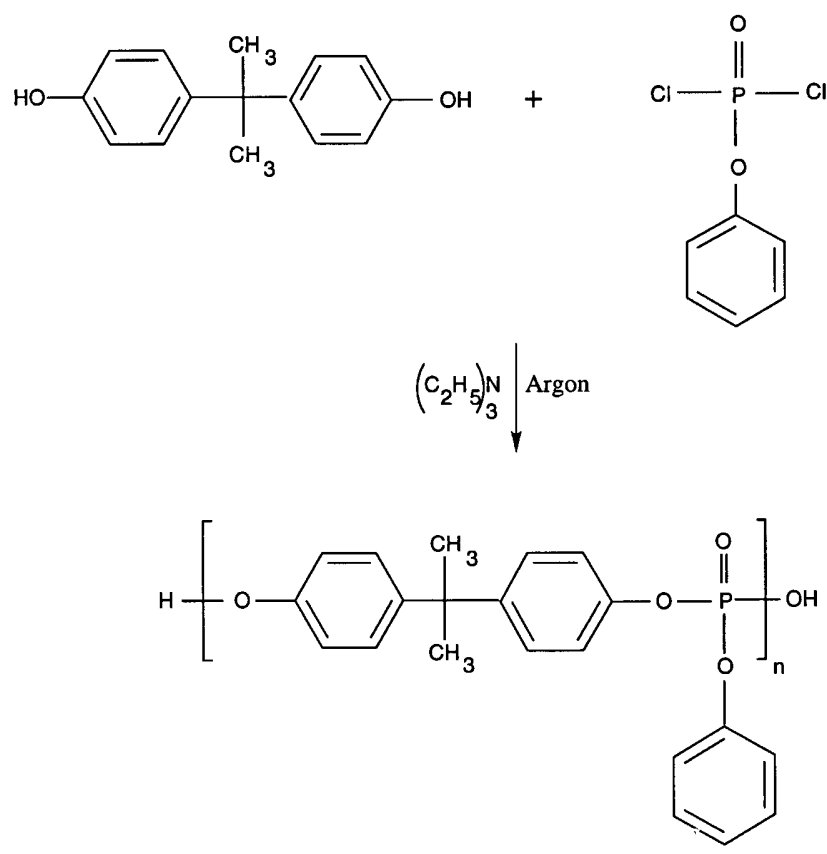

Figure 1. Synthesis of polyphosphate polymer by addition of phenyl-phosphodichloridate $\left(\mathrm{C}_{6} \mathrm{H}_{5} \mathrm{OP}[\mathrm{O}] \mathrm{Cl}_{2}\right)$ to bisphenol A $\left(\left[\mathrm{CH}_{3}\right]_{2} \mathrm{C}\left[\mathrm{C}_{6} \mathrm{H}_{4} \mathrm{OH}\right]_{2}\right)$ in the presence of triethylamine $\left(\mathrm{C}_{2} \mathrm{H}_{5}\right)_{3} \mathrm{~N}$ and argon (Ar) gas.

over $\mathrm{CaH}_{2}$ at $60^{\circ} \mathrm{C}$ for $8 \mathrm{~h}$. The final polymer was soluble in acetone and tetrahydrofuran (THF).

\section{Polymer characterization}

Elemental analysis of the polymer was performed on two samples using X-ray fluorescence spectroscopy (Galbraith Laboratories, Inc., Knoxville, TN). Molecular weight analyses on two specimens were accomplished via gel permeation chromatography (GPC, Waters Chromatographic System, Marlborough, MA). The GPC system consisted of a 996 photodiode array detector, 600E multisolvent delivery system, Autosampler 717, and Millennium chromatographic software. The GPC columns were the ultrastyragel type with pore sizes of 100,500 , and 1,000 $⿱$. Polystyrene standards (Polyscience, Inc., Warrington, PA) in the molecular weight range of 1 to $30 \mathrm{kDa}$ and $\mathrm{M}_{\mathrm{w}} / \mathrm{M}_{\mathrm{n}} \leq 1.1$ were used to calibrate the GPC instrument. GPC analysis was performed under the following operating conditions: column pressure, $50 \mathrm{~kg} / \mathrm{cm}^{2}$; temperature, $37^{\circ} \mathrm{C}$; THF eluent flow rate, $0.8 \mathrm{~mL} / \mathrm{min}$; and run times, 0 to $35 \mathrm{~min}$. An ultraviolet (UV) detector was used to monitor the degradation products at $254 \mathrm{~nm}$.

Fourier transform infrared spectroscopy (FTIR) was performed on two samples using a Nicolet 60 SX system. The detector was a deutrated triglycine sulfate (DTGS)/polyethylene with a $\mathrm{KBr}$ beam splitter. The spectra were obtained from $400-4,000 \mathrm{~cm}^{-1}$ and collected using a scan rate of 32 for each sample. Samples 
TABLE I

Starting Reagents, Catalyst, Solvents, and Drying Agents for Polyphosphate Synthesis

\begin{tabular}{|c|c|c|c|c|}
\hline Chemical & Mol. Wt. & Density $(\mathrm{g} / \mathrm{mL})$ & Supplier & Purity/Grade \\
\hline \multicolumn{5}{|l|}{ Starting Reagents } \\
\hline Bisphenol A $\left(\left[\mathrm{CH}_{3}\right]_{2} \mathrm{C}\left[\mathrm{C}_{6} \mathrm{H}_{4} \mathrm{OH}\right]_{2}\right)$ & 228 & 1.20 & $\begin{array}{l}\text { Fluka Chemical } \\
\text { Ronkonkoma, NY }\end{array}$ & $98 \%$ \\
\hline $\begin{array}{l}\text { Phenylphosphodichloridate } \\
\qquad\left(\mathrm{C}_{6} \mathrm{H}_{5} \mathrm{OP}[\mathrm{O}] \mathrm{Cl}_{2}\right)\end{array}$ & 211 & 1.41 & $\begin{array}{l}\text { Eastman Kodak } \\
\text { Rochester, NY }\end{array}$ & $\begin{array}{l}97 \% \\
\text { vac. distilled }\end{array}$ \\
\hline \multicolumn{5}{|l|}{ Solvents } \\
\hline Toluene $\left(\mathrm{C}_{6} \mathrm{H}_{5} \mathrm{CH}_{3}\right)$ & 92 & 0.87 & $\begin{array}{l}\text { Aldrich Chemical } \\
\text { Milwaukee, WI }\end{array}$ & HPLC \\
\hline Hexane $\left(\mathrm{CH}_{3}\left[\mathrm{CH}_{2}\right]_{4} \mathrm{CH}_{3}\right)$ & 86 & 0.66 & $\begin{array}{l}\text { Aldrich Chemical } \\
\text { Milwaukee, WI }\end{array}$ & HPLC \\
\hline Acetone $\left(\mathrm{CH}_{3} \mathrm{COCH}_{3}\right)$ & 58 & 0.79 & $\begin{array}{l}\text { Aldrich Chemical } \\
\text { Milwaukee, WI }\end{array}$ & HPLC \\
\hline \multicolumn{5}{|l|}{ Catalyst } \\
\hline Triethylamine $\left(\mathrm{C}_{2} \mathrm{H}_{5}\right)_{3} \mathrm{~N}$ & 101 & 0.73 & $\begin{array}{l}\text { Aldrich Chemical } \\
\text { Milwaukee, WI }\end{array}$ & $99 \%$ \\
\hline \multicolumn{5}{|l|}{ Drying Agents } \\
\hline Phosphorus Pentoxide $\left(\mathrm{P}_{2} \mathrm{O}_{5}\right)$ & 142 & - & $\begin{array}{l}\text { Aldrich Chemical } \\
\text { Milwaukee, WI }\end{array}$ & $98 \%$ \\
\hline Calcium Hydride $\left(\mathrm{CaH}_{2}\right)$ & 42 & - & $\begin{array}{l}\text { Mallinckrodt Specialty Chemicals Co., } \\
\text { Paris, KY }\end{array}$ & $99 \%$ \\
\hline Molecular Sieves & - & - & $\begin{array}{l}\text { Aldrich Chemical } \\
\text { Milwaukee, WI }\end{array}$ & $99 \%$ \\
\hline
\end{tabular}

for FTIR analysis were cast from an acetone solution $(1.0 \mathrm{w} / \mathrm{v} \%)$ onto clean $\mathrm{KBr}$ plates and subsequently dried at $60^{\circ} \mathrm{C}$ for $12 \mathrm{~h}$ before analysis.

\section{Hydrolytic stability of polymer}

Thirty six samples of synthesized polymer, each weighing $0.1 \mathrm{~g}$ and having dimensions of $12.5 \times 12.5$ $\times 25.0 \mathrm{~mm}^{3}$ were formed in a teflon mold. Twelve samples each were tested for hydrolytic stability in $10 \mathrm{~mL}$ of $0.1 \mathrm{M}$ PBS at $\mathrm{pH}=7.4,37^{\circ} \mathrm{C} ; 100 \%$ fetal bovine serum (FBS, Hyclone ${ }^{\circledR}$ Laboratories, Inc., Logan, UT) at $\mathrm{pH}=7.5$; and $10 \%$ FBS in $\mathrm{PBS}$ at $\mathrm{pH}=7.5,37^{\circ} \mathrm{C}$. The polymer residue was rinsed briefly with deionized $\mathrm{H}_{2} \mathrm{O}$, dried over $\mathrm{CaH}_{2}$, and weighed at various times $(6,12,24,36,48,60,72 \mathrm{~h})$ to determine the weight loss. At each time point, the dissolution media were replaced with fresh buffer, serum, or serum/buffer.

Hydrolysis breakdown products were analyzed for two of the samples immersed in PBS and serum using an aqueous GPC setup with a gradient of $1.5 \% \mathrm{NaNO}_{3}$. Control samples contained two model compounds in solution-a potassium salt of bisphenol A and phenol in a molar ratio of 1:1. The aqueous system had a series of ultrahydrogel columns with pore sizes of 120, 250, and $500 \AA$. The GPC was calibrated using a series of polyethylene glycol standards with a molecular weight range of $0.1-22 \mathrm{kDa}$. The operating conditions for aqueous GPC were column pressure $48 \mathrm{~kg} / \mathrm{cm}^{2}$; temperature $37^{\circ} \mathrm{C}$; flow rate $1.0 \mathrm{~mL} / \mathrm{min}$; and run time 0 to $40 \mathrm{~min}$. A UV detector was used to monitor the degradation products at $254 \mathrm{~nm}$. Molecular weights were determined by deconvoluting the GPC curves with a Gaussian function using the Peak Fit ${ }^{\mathrm{TM}}$ program (Jandel Scientific, Inc., San Rafael, CA).

\section{Incorporation of OP-1 into synthetic polymer}

The protein in 50\% acetonitrile and $0.1 \%$ TFA was physically mixed with the polyphosphate dissolved in acetone. The protein and polymer adduct had a final concentration of $1.0 \mu \mathrm{g}$ protein per $1 \mathrm{mg}$ of polyphosphate. The resultant mixture was then poured into a teflon mold $\left(12.5 \times 12.5 \times 25.0 \mathrm{~mm}^{3}\right)$ and freeze dried at $-70^{\circ} \mathrm{C}$ until further use.

\section{Protein release from polymer}

Measurements of the time release of OP-1 were undertaken by exposing $2 \mathrm{mg}$ of matrix containing OP1 to $0.5 \mathrm{~mL}$ of PBS or bovine serum at $37^{\circ} \mathrm{C}$. The amount of OP-1 was based upon release concentration vs. time profiles of OP-1 in a collagen matrix. Six samples of the formulated delivery device were exposed to each medium using the same protocol as in the polymer dissolution study. At each time point, the liquid was withdrawn and the supernatants were vortexed for $3 \mathrm{~min}$. Samples were incubated for $30 \mathrm{~min}$ at room temperature and centrifuged for $30 \mathrm{sec}$ at $10,000 \times \mathrm{g}$. The supernatants $(20 \mu \mathrm{L})$ were then analyzed by reverse phase HPLC (Applied Biosystems Industry, Foster City, CA). Analytical HPLC analysis of the OP-1 was performed using a UV variable wavelength detec- 
tor system at 210 and $254 \mathrm{~nm}$. Protein absorbance was measured at $210 \mathrm{~nm}$, while polymer concentration was quantified using the $254 \mathrm{~nm}$ setting. A C-18 column (Applied Biosystems Industry, Foster City, CA) was used to separate the protein from the polymer with 5 $\mu \mathrm{m}$ particle size, $300 \AA$ pore size, and column dimensions of $1 \times 150 \mathrm{~mm}$. A programmed gradient of solvent $A(0.1 \%$ trifluoracetic acid for $25 \mathrm{~min})$ followed by solvent B (25-56\% with a composition of $0.095 \%$ TFA in acetonitrile) was utilized. Flow rate was 0.6 $\mathrm{mL} / \mathrm{min}$. The amount of OP-1 released was determined from a calibration curve of OP-1 standards.

\section{Statistical analyses}

Experimental values of polymer mass and concentration of OP-1 are reported as the mean of 12 and 6 samples, respectively, at each time point \pm the standard deviation of the mean. Comparisons of polymer weight loss and protein release profiles in the different media were made using an ANOVA at each time point. Statistical significance for all measures was set at $p<$ 0.05 . Linear and nonlinear regression analyses were used to quantify the time course of polymer weight loss, molecular weight reduction, and protein release. For all regression analyses, adjusted coefficients of determination, $\mathrm{R}_{\mathrm{adj}}^{2}$, were determined, and Student's $t$ tests were performed to determine whether the regression coefficients were statistically significant. Partial F tests were used to determine whether linear or nonlinear models provided a better fit.

\section{RESULTS}

\section{Polymer synthesis and characterization}

Table II compares the experimental and calculated atomic weight percentages of carbon, hydrogen, oxygen, and phosphorus for the polyphosphate. The calculated values were determined by adding the atomic weights of the individual elements as a function of the total subunit molecular weight of the polymer. Experimental and calculated values are within 5 weight percent.

TABLE II

Elemental Analysis of Polyphosphate

\begin{tabular}{lcc}
\hline Element & Experimental $\mathrm{Wt} \%$ & Theoretical $\mathrm{Wt} \%$ \\
\hline Carbon & 62.0 & 64.0 \\
Oxygen & 24.3 & 22.3 \\
Hydrogen & 10.3 & 10.0 \\
Phosphorus & 3.5 & 3.7 \\
\hline
\end{tabular}

The IR spectrum shown in Figure 2 indicates the hydrogen- and nonhydrogen-bonded phosphate groups $\mathrm{v}(\mathrm{P}=\mathrm{O})$ of the polymer backbone at 1,196 and $1,168 \mathrm{~cm}^{-1}$, respectively. The polyphosphate also contains terminated hydroxyl end groups $\mathrm{v}(\mathrm{O}-\mathrm{H})$ at $3,300 \mathrm{~cm}^{-1}$. These three infrared bands confirm the polyphosphate structure. The $\mathrm{v}(\mathrm{P}-\mathrm{OH})$ band at 2,700 $2,500 \mathrm{~cm}^{-1}$, which indicates the presence of a phosphonate linkage, and the band at 2,440-2,350 $\mathrm{cm}^{-1}$ for $\mathrm{v}(\mathrm{P}-$ $\mathrm{H})$, which is attributed to phosphite linkages, possible by-products of the reaction, are both absent from this spectrum, further confirming the existence of phosphate groups. Other IR bands include: $\mathrm{v}(\mathrm{C}-\mathrm{H})$ and $\mathrm{V}\left(\mathrm{CH}_{3}\right)$ from bisphenol A at 2,964 $\mathrm{cm}^{-1}$, the $\mathrm{v}(\mathrm{C}=\mathrm{C})$ aromatic band at $1,590 \mathrm{~cm}^{-1}, \mathrm{v}(\mathrm{P}-\mathrm{O}-\mathrm{C})$ asymmetric linkage at $971 \mathrm{~cm}^{-1}$, and $\mathrm{v}(\mathrm{P}-\mathrm{O}-\mathrm{C})$ symmetric band at $837 \mathrm{~cm}^{-1}$.

\section{Hydrolytic stability of polymer}

The polymer is fully dissolved after $60 \mathrm{~h}$ in PBS and after $72 \mathrm{~h}$ in bovine serum (Fig. 3). Polymer dissolution was significantly different between PBS and serum at each non-zero time point $(p<0.01)$. Regression analysis of polymer weight loss as a function of time shows that the weight loss in PBS follows a secondorder equation:

$$
\mathrm{W}(t)_{\mathrm{PBS}}=-0.024 t^{2}+3.051 t+0.176 ; \mathrm{R}_{\mathrm{adj}}^{2}=0.993
$$

where $\mathrm{W}(t)$ is the weight loss as a function of time, $t$ in hours. The loss of polymer in bovine serum follows a linear first-order equation, or one-stage weight loss:

$$
\begin{gathered}
\mathrm{W}(t)_{100 \% \mathrm{FBS}}=1.339 t+2.578 ; \mathrm{R}_{\mathrm{adj}}^{2}=0.996 \\
\mathrm{~W}(t)_{10 \% \mathrm{FBS}}=1.412 t+0.351 ; \mathrm{R}_{\mathrm{adj}}^{2}=0.998
\end{gathered}
$$

To identify the specific polyphosphate degradation scheme, the hydrolytic by-products were separated after 60- and 72-h exposures to PBS and sera, respectively, by aqueous GPC (Fig. 4). Two major peaks, in the ratio of approximately 2.25 to 1 , are noted on the GPC plot for the control sample. The first chromatographic peak at $20.5 \mathrm{~min}$ is the bisphenol- $\mathrm{A}$ ( $\mathrm{K}^{+}$salt), and the second peak at $23.0 \mathrm{~min}$ is the phenol. The peak height ratios of bisphenol A to phenol were 1.7 and 1.4 for the PBS and the serum-immersed samples, respectively. A proposed degradation model is given in Figure 5 based upon the presence of bisphenol A and phenol in the PBS and sera extracts.

Figures $6 \mathrm{a}$ and $6 \mathrm{~b}$ depict changes in molecular weight with hydrolysis time. Longer retention times on the $\mathrm{x}$ axis correspond to a decrease in the molecular weight of the polymer. The untreated, noncrosslinked control polymer exhibited a unimodal molecular weight distribution. The GPC plots for the samples immersed in bovine serum (Fig. 6a) demonstrate only a decrease in molecular weight; the polydispersity, or 


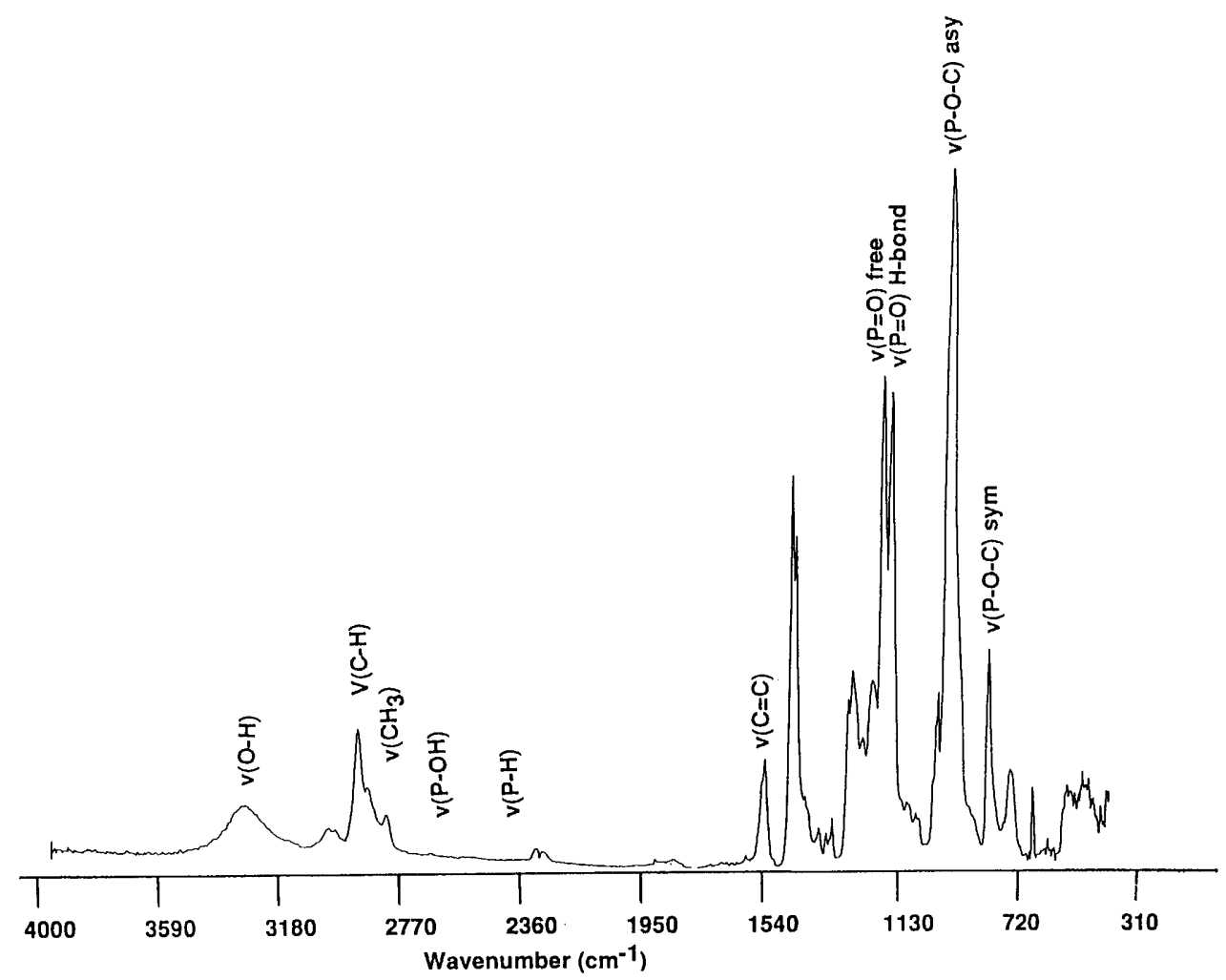

Figure 2. Infrared analysis of the polyphosphate polymer. The three infrared bands, v(O-H) $\left(3,300 \mathrm{~cm}^{-1}\right), \mathrm{v}(\mathrm{P}=\mathrm{O})$ free $\left(1,196 \mathrm{~cm}^{-1}\right)$, and $\mathrm{v}(\mathrm{P}=\mathrm{O}) \mathrm{H}$-bonded $\left(1,168 \mathrm{~cm}^{-1}\right)$ were used to confirm the polyphosphate structure. The $\mathrm{v}(\mathrm{P}-\mathrm{OH})$ band $\left(2,700-2,500 \mathrm{~cm}^{-1}\right)$, due to a polyphosphonate structure, and the $\mathrm{v}(\mathrm{P}-\mathrm{H})$ band $\left(2,400-2,350 \mathrm{~cm}^{-1}\right)$, due to a polyphosphite structure, are both absent, further confirming the existence of a polyphosphate.

molecular weight distribution, was not affected by increasing hydrolysis time. Comparison of the control and PBS chromatograms (Fig. 6b) shows that with increasing hydrolysis time the unimodal distribution of the polymer converts to a bimodal distribution pattern, or two separate GPC peaks.
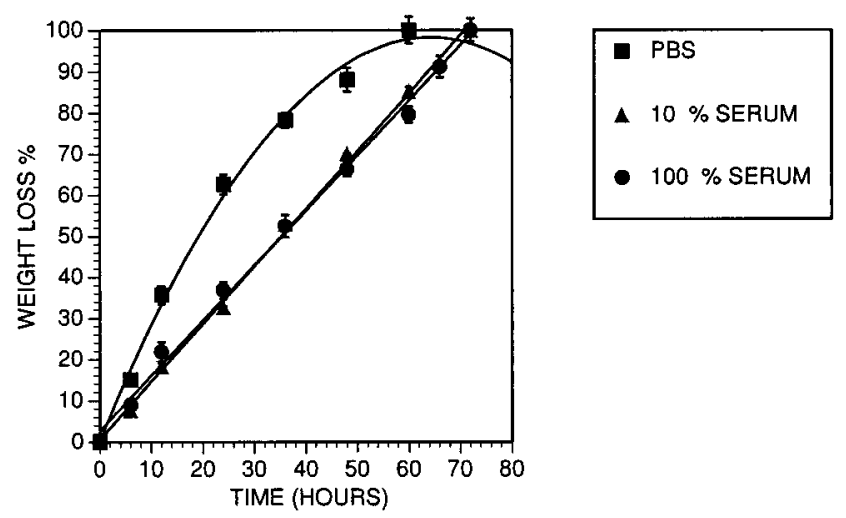

Figure 3. Percent weight loss of polyphosphate after exposure to PBS and bovine sera as a function of time. Degradation kinetics for the sera-treated polymer are represented by linear equations, whereas the PBS-treated polymer is described by a second-order polynomial. The time for $100 \%$ weight loss is longer in sera than in PBS.
Upon hydrolysis, the number-average molecular weight $\left(\mathrm{M}_{\mathrm{n}}\right)$ of the polymer decreased with increasing exposure time to both PBS and serum. The decrease in molecular weight with time (Fig. 7) shows a secondorder decrease in PBS and a linear relationship in serum:
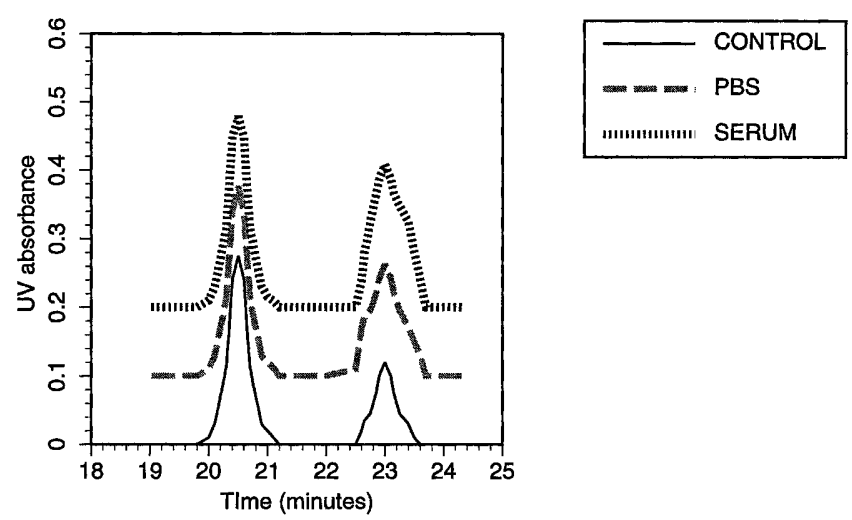

Figure 4. Comparison of the GPC chromatograms. The two model compounds, bisphenol A and phenol, are the two peaks depicted in the control chromatogram. The ratios of bisphenol A to phenol peaks are similar for the PBS- and sera-immersed samples. 
<smiles>CC(C)Oc1ccc(C(C)(C)c2ccc(OP3(=O)CCCC3(O)Oc3ccccc3)cc2)cc1</smiles><smiles>CC(C)(c1ccc(O)cc1)c1ccc(O)cc1</smiles>

Figure 5. Proposed hydrolytic degradation mechanism for the polyphosphate.

$$
\begin{gathered}
\mathrm{M}(t)_{\mathrm{PBS}}=4.521 t^{2}-550.0 t+17942 ; \mathrm{R}_{\mathrm{adj}}^{2}=0.922 \\
\mathrm{M}(t)_{\text {Serum }}=-225.1 t+16,679 ; \mathrm{R}_{\mathrm{adj}}^{2}=0.984
\end{gathered}
$$

\section{Protein release from polymer}

Protein release is complete after $48 \mathrm{~h}$ in PBS and after $60 \mathrm{~h}$ in serum (Fig. 8). Measured release of OP1 from PBS and serum are significantly different $(p<$ 0.01 ), except at $6 \mathrm{~h}$. Nonlinear regression analysis of OP-1 release in PBS as a function of time is given by:

$$
\begin{aligned}
\mathrm{P}(t)_{\mathrm{PBS}}= & -8.557 \times 10^{-4} t^{2}+7.866 \times 10^{-2} t+0.129 ; \\
& \mathrm{R}_{\mathrm{adj}}^{2}=0.877
\end{aligned}
$$

where $\mathrm{P}(t)$ is the weight percent of protein released with time, $t$. The release of OP- 1 in serum at any time, $t$ may be presented by:

(a)

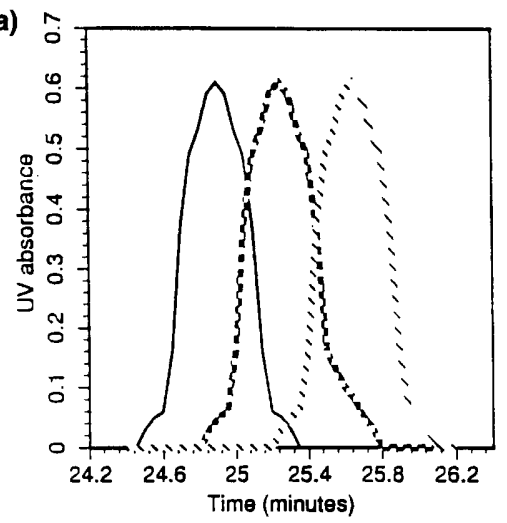

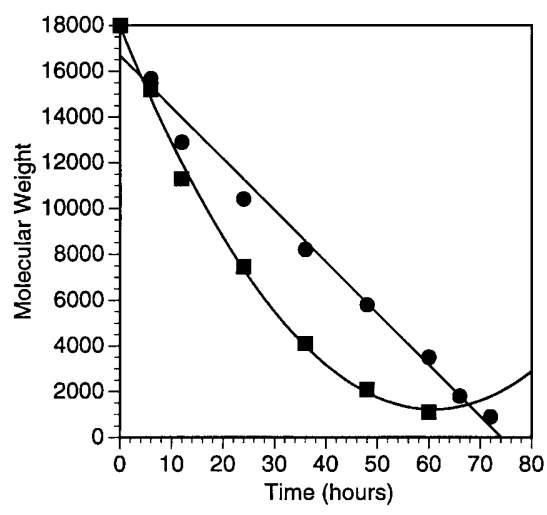

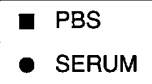

Figure 7. Relationship between molecular weight and time of hydrolysis. The polymer exposed to serum is linear while samples exposed to PBS display a quadratic relationship.

$$
\begin{aligned}
& \mathrm{P}(t)_{\text {Serum }}=-4.257 \times 10^{-4} t^{2}+5.621 \times 10^{-2} t+0.128 \\
& \mathrm{R}_{\mathrm{adj}}^{2}=0.977
\end{aligned}
$$

\section{DISCUSSION}

\section{Polymer synthesis and characterization}

Synthesis of polyphosphate polymers by a twophase interfacial condensation procedure already has been reported. ${ }^{31,32}$ In this study, a single catalyst and solvent system was used instead, and the reaction was run at higher temperatures to increase the reaction yield. In previous studies, the synthesized polymer contained a bimodal molecular weight distribution due to unreacted short chain oligomers. ${ }^{19,31}$ The polyphosphate synthesized in this study had a unimodal distribution (Fig. 6). Once the polymerization was complete, the polymer was precipitated in hexane, which most likely removed any short-chain oligomers.

Figure 6. GPC chromatograms of the polyphosphate: (a) control polyphosphate and polyphosphate after bulk degradation in bovine serum; (b) control polyphosphate and polyphosphate after bulk degradation in PBS. Degradation of the polymer in serum preserves the unimodal distribution of the polymer while in PBS the molecular weight distribution is converted to a bimodal form. 


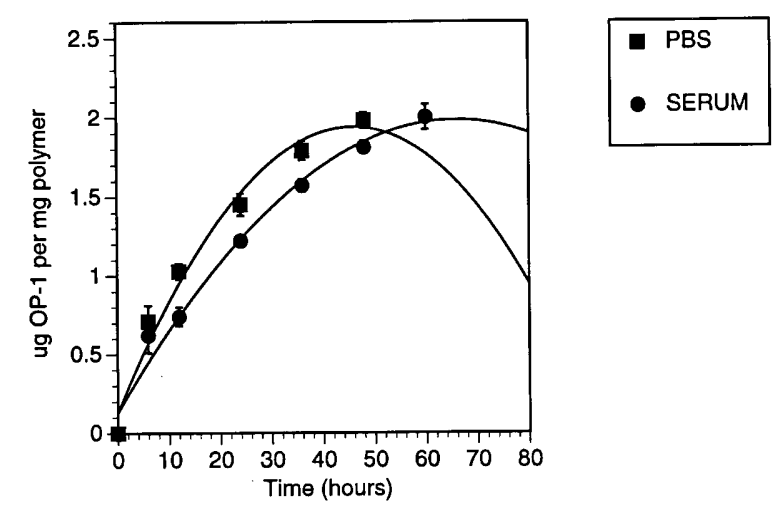

Figure 8. Release of OP-1 from the polyphosphate as a function of time. Release kinetics of OP-1 in both PBS and serum are described by second-order polynomials. Release of OP-1 in serum is slower than in PBS.

Experimental IR band assignments are in agreement with literature values, confirming the structure of the polyphosphate. ${ }^{33,34}$ Experimental and calculated atomic weight percents are within $5 \%$ of each other, and these values provide further evidence that the polymer is a polyphosphodiester. Both the FTIR and elemental analyses failed to show the existence of phosphonate or phosphite polymers, which are possible by-products of the reaction.

\section{Hydrolytic stability of polymer}

The characteristic backbone of polyphosphate polymers is the phosphodiester linkage, which is hydrolytically sensitive. Therefore, the rate of hydrolysis is primarily controlled by the side chains and molecular weight of the polymer. In theory, hydroxyl ions should cleave the phospho-ester bond, yielding a diol and a phosphate. Characterization of these polymer degradation products is important in the development of a polymer as a candidate biomaterial since the degradation products have a direct effect on the safety and efficacy of the device.

The molecular weight of the polyphosphate decreased following immersion in both PBS and serum, implying backbone cleavage. The mass loss kinetics were similar to and followed the kinetics of molecular weight reduction. However, the number-average molecular weight of the polyphosphate decreased faster and with higher order kinetics in PBS than in serum. The slower dissolution rate of the polymer in bovine serum may be explained by the presence of $\mathrm{Ca}^{2+}$ ions in serum compared to PBS, which contains no $\mathrm{Ca}^{2+}$. The ability of free $\mathrm{Ca}^{2+}$ to complex with the polyphosphate backbone may lower the degradation rate of the polymer. The polyphosphate polymer was rapidly cleaved as compared to polyphosphates that contain crosslinkages and can have cleavage times greater than 30 days. ${ }^{31}$
The linear degradation kinetics in serum may be explained by the direct chelation of $\mathrm{Ca}^{2+}$ or by enzymatic cleavage of the polymer by alkaline phosphatase in the serum, a natural enzyme known to use p-nitrophosphobenzene as a substrate. ${ }^{35}$ Therefore, it is conceivable that the aromatic polyphosphate backbone may be a substrate for this enzyme. The enzyme may assume an exact conformation state that cleaves the polymer at a linear rate. In PBS, the polymer undergoes a quadratic degradation. One possible explanation for this may be the presence of an excess amount of phosphate ion in PBS compared to serum. Excess phosphate may buffer the degradation process, or the phosphate may actually be able to phosphorylate the hydroxyl groups on the chain ends of the polymer. This has been noted for proteins and saccharides exposed to PBS. ${ }^{36}$ These mechanisms may ultimately explain the change in degradation kinetics of the polymer in different in vitro media.

The decrease in number-average molecular weight with time may be represented by a simple theory of random degradation, which states that the degree of degradation, $\Delta_{\mathrm{d}}$, of a polymer at a certain stage of the degradation process is expressed by:

$$
\Delta_{\mathrm{d}}=s /\left(\mathrm{M}_{0}+1\right)
$$

where $s$ is the number of broken links per chain and $\mathrm{M}_{0}$ is the number-average chain length of the polyphosphate before degradation. When $\mathrm{M}_{0}$ is large, Equation (7) reduces to:

$$
\Delta_{\mathrm{d}}=\mathrm{s} / \mathrm{M}_{0}
$$

The number-average chain length, $\mathrm{M}_{\mathrm{t}}$, at any time, $t$ during degradation can be expressed by:

$$
\mathrm{M}_{t}=\mathrm{M}_{0} /(\mathrm{s}+1)
$$

When the rate of breaking links is independent of both the position of the link in the chain and the chain length, as is the case for hydrolytic degradation (random scission of the polymer chains), the process is a linear function of time that can be expressed by:

or:

$$
\begin{gathered}
\Delta_{\mathrm{d}}=\mathrm{k}_{\mathrm{d}} t \\
\mathrm{~s}=\mathrm{M}_{0} \mathrm{k}_{\mathrm{d}} t
\end{gathered}
$$

where $t$ is the time of hydrolysis and $k_{d}$ is the hydrolytic degradation constant. Combining equations (9) and (11) leads to:

$$
1 / \mathrm{M}_{t}-1 / \mathrm{M}_{0}=\mathrm{k}_{\mathrm{d}} t
$$

Equation (12) shows that early in the degradation process the number-average chain length should decrease linearly as a function of time. The results of this model are not in absolute terms since all of the mass fractions produced during the degradation of the polymer, such as monomers or short chain oligomers, must also be taken into account. ${ }^{31}$ Other assumptions in the degra- 
dation model are that the control polymer must have a unimodal molecular weight distribution and that the polymer must not have intermolecular crosslinks.

This linear degradation model may be used to represent the degradation of the polyphosphate in serum, as shown by the linear plot given in Figure 7:

$$
\begin{aligned}
\left(1 / \mathrm{M}_{0}-1 / \mathrm{M}_{t}\right) \times 10^{6} & =-1.01 \times 10^{-2} t+0.136 ; \\
\mathrm{R}_{\mathrm{adj}}^{2} & =0.604
\end{aligned}
$$

The degradation of the polyphosphate in PBS solution is best described by a second-order polynomial, which may indicate a two-stage degradation model or a combination of linear and quadratic effects on the hydrolytic scission of the polymer:

$$
\begin{gathered}
\left(1 / \mathrm{M}_{0}-1 / \mathrm{M}_{t}\right) \times 10^{6}=-3.423 \times 10^{-4} t^{2}+7.437 \\
\times 10^{-3} t-3.417 \times 10^{-2} ; \mathrm{R}_{\text {adj }}^{2}=0.831
\end{gathered}
$$

\section{Protein release from polymer}

The slower release of OP-1 in serum compared to PBS may be related to the same effect noted in the polymer dissolution studies; the protein backbone containing polycarboxylate sequences may represent sites for $\mathrm{Ca}^{2+}$ complexation, slowing hydrolytic breakdown of the polymer. ${ }^{37-39}$ The slow release in serum might also be explained by the possibility that OP-1 binds to serum proteins, creating a larger complex to diffuse through and thus slowing its release from the remaining polymer matrix. It appears that OP-1 release from the matrix may be governed by diffusion, bulk polymer degradation, complexation of free $\mathrm{Ca}^{2+}$, and OP-1 serum protein interactions. The fact that all OP-1 in the matrix was released before polymer dissolution was complete indicates that the mechanism of release may be more diffusion controlled than polymer degradation controlled.

Although this first generation of polyphosphate underwent total dissolution in only 3 days, the ability to change the composition of the starting materials and modify pendant side chains allows for variation in molecular weight, the degree of hydrophilicity / hydrophobicity, and alteration of other properties. For example, poly(bisphenol A-ethylphosphate) has been shown to degrade faster than poly(bisphenol A-phenylphosphate. ${ }^{19}$ Since hydrolysis is a function of pendant side chains, material modifications should focus on these side chains, which are more susceptible to cleavage and degradation. ${ }^{19}$

Studying in vitro release of OP-1 from a matrix is important for several reasons. First, it assesses the reproducibility of polymer-protein matrix formation. Second, it may determine if the stability of the protein is retained after matrix formation. Third, it may determine how structural variation in the protein may affect the osteogenic response to a local cell population. Studies on growth-factor release typically use only PBS as a dissolution medium and therefore do not assess any effects of proteins that may contribute to the release of the OP- 1 protein or its degradation. ${ }^{13}$

It is not known from these studies how the in vitro release kinetics of OP-1 correlate with biological activation. The physiology, pharmacokinetics, and mechanisms of action of OP-1 are not known. The optimal concentration ranges for biological efficacy of this particular protein also are unknown. In general, bone repair is dependent on animal species, anatomic site, age, environment, and type/degree of insult. Characterizing the synergy among material degradation, growthfactor release, and bone repair is important for achieving a long-range goal of augmenting bone healing in vivo. In terms of meeting such an objective, the biological activity of any biological agent following release from a polymer needs to be adequate and perhaps unchanged from its activity state prior to mixing with the polymer. At this time it is unclear whether or not the reagents used to mix the protein and phosphate (acetone, acetonitrile, and TFA) deactivate the protein. Nevertheless, in this study an important first step, namely synthesis of a polymer and demonstrated release of the protein, have been achieved.

Characterizing the biological response to newly synthesized materials is another necessary step toward ultimately bringing such a carrier to in vivo service. An additional rationale for using polyphosphate materials is that both in vitro cytotoxicity and ex vivo histology performed on polyphosphates and their derivatives demonstrate this class of polymers behaves equivalently to or better than other polymers that already are in clinical service. ${ }^{19,40,41}$ Histological results from different polyphosphates implanted in rabbit soft tissue indicate minor encapsulation and, for some polyphosphate derivatives, slight lymphocyte, giant cell, or macrophage activity. ${ }^{19}$ For all polyphosphate derivatives there were no chronic, long-term ( $>30$ weeks) reactions..$^{19}$ In general, phenol has a long history as a topical dental treatment. ${ }^{42-44}$ In vitro cytotoxicity studies on the other degradation product of this polyphosphate, bisphenol-A, have demonstrated that the concentration of bisphenol-A, which inhibits $50 \%$ of DNA synthesis and protein synthesis, is less than that of many methacrylate-based materials and their monomers. ${ }^{40,41}$

\section{CONCLUSIONS}

A biodegradable polyphosphate has been synthesized as a potential carrier for bioactive molecules, and the following conclusions are noted: 1$)$ the polyphosphate was prepared in high yields $(90 \%)$ and contained no detectable impurities; 2) polymer degradation was slower in bovine serum than in PBS. Degradation in 
PBS followed a second-order equation while in bovine serum it was modeled by a linear one-stage model; 3 ) the polyphosphate degraded into two low-molecularweight compounds, bisphenol A and phenol. Mass loss followed molecular weight reduction. Molecularweight reduction fit a random degradation model, indicating the polymer underwent bulk degradation rather than surface degradation; and 4) the OP-1 release from the polyphosphate was slower in bovine serum than in PBS. Release of OP-1 in both PBS and bovine serum is represented by second-order functions.

This work was supported, in part, by NIH DE07057. The authors would like to thank Creative Biomolecules, Incorporated, Hopkinton, MA, for donation of the bone protein OP1 and also for their helpful suggestions for developing the release kinetics protocol for OP-1. We are also grateful to Bruce Rutherford for his helpful discussions and comments, and to Waters Chromatography, Ann Arbor, MI, for performing the GPC analyses.

\section{References}

1. T. K. Sampath, J. C. Maliakal, P. V. Hauschka, W. K. Jones, H. Sasak, R. F. Tucker, K. H. White, J. E. Coughlin, M. M. Tucker, R. H. L. Pang, C. Corbett, E. Ozkaynak, H. Oppermann, and D. C. Rueger, "Recombinant human osteogenic protein-1 (OP-1) induces new bone formation in vivo with a specific activity comparable with natural bovine osteogenic protein and stimulates osteoblast proliferation and differentiation in vitro," J. Biol. Chem., 267, 20352-20362 (1992).

2. L. J. Marden, J. O. Hollinger, A. Chaudhari, T. Turek, R. G. Schaub, and E. Ron, "Recombinant human bone morphogenetic protein-2 is superior to demineralized bone matrix in repairing craniotomy defects in rats," J. Biomed. Mater. Res., 28, 1127-1138 (1994).

3. M. E. Bolander and G. Balian, "The use of demineralized bone matrix in the repair of segmental defects," J. Bone J. Surg., 68A, 1264-1274 (1986).

4. R. W. Katz, J. O. Hollinger, and A. H. Reddi, "The functional equivalance of demineralized bone and tooth matrices in ectopic bone induction," J. Biomed. Mater. Res., 27, 239-245 (1993).

5. C. J. Damien, J. R. Parsons, A. B. Prewett, D. C. Rietveld, and M. C. Zimmerman, "Investigation of an organic delivery system for demineralized bone matrix in a delayed-healing cranial defect model," J. Biomed. Mater. Res., 28, 553-561 (1994).

6. E. Arnaud, C. Morieux, M. Wybier, and M. C. de Vernejoul, "Potentiation of transforming growth factor (TGF$\beta 1$ ) by natural coral and fibrin in a rabbit cranioplasty model," Calcif. Tissue Int., 54, 493-498 (1994).

7. R. Muzzarelli, V. Baldasarre, F. Conti, P. Ferrara, G. Biagini, G. Gazzanelli, and V. Vasi, "Biological activity of chitosan: Ultrastructural study," Biomaterials, 9, 247252 (1988).

8. H. Ohgushi, M. Okumura, S. Tamai, E. C. Shors, and A. I. Caplan, "Marrow cell-induced osteogenesis in porous hydroxyapatite and tricalcium phosphate: A comparative histomorphometric study of ectopic bone formation," J. Biomed. Mater. Res., 24, 1563-1570 (1993).
9. S. F. Rosenblum, S. Frenkel, J. R. Ricci, and H. Alexander, "Diffusion of fibroblast growth factor from a plaster-of-Paris carrier," J. Appl. Biomater., 4, 67-72 (1993).

10. K. Ono, T. Yamamuro, T. Nakamura, and T. Kokubo, "Apatite-wollastonite containing less ceramic granulefibrin mixture as a bone graft filler: Use with low granular density," J. Biomed. Mater. Res., 24, 11-20 (1990).

11. P. Ducheyne, A. El-Ghannam, and I. Shapiro, "Effect of bioactive glass templates on osteoblast proliferation and in vitro synthesis of bone-like tissue," J. Cell. Biochem., 56, 162-167 (1994).

12. S. L. Stupp and G. W. Ciegler, "Organoapatites: Materials for artificial bone. I. Synthesis and microstructure," J. Biomed. Mater. Res., 26, 169-183 (1992).

13. W. R. Gombotz, S. C. Pankey, L. S. Bouchard, D. K. Phan, and P. A. Puolakkainen, "Stimulation of bone healing by transforming growth factor- $\beta 1$ released from polymeric or ceramic implants," J. Appl. Biomater., 5, 141-150 (1994).

14. A. G. Mikos, Y. Bao, L. G. Cima, D. E. Ingber, J. P. Vacanti, and R. Langer, "Preparation of poly(glycolic acid) bonded fiber structures for cell attachment and transplantation," J. Biomed. Mater. Res., 27, 183-189 (1993).

15. S. Miyamoto, K. Takaoka, T. Okada, H. Yoshikawa, J. Hashimoto, S. Suzuki, and K. Ono, "Evaluation of polylactic acid homopolymers as carriers for bone morphogenetic protein," Clin. Orthop., 278, 274-285 (1992).

16. S. C. Lee, M. Shea, M. A. Battle, K. Kozitza, E. Ron, T. Turek, R. G. Schaub, and W. C. Hayes, "Healing of large segmental defects in rat femurs is aided by rhbmp-2 in PLGA matrix," J. Biomed. Mater. Res., 28, 1149-1156 (1994).

17. S. Miyamoto, K. Takaoka, T. Okada, H. Yoshikawa, J. Hashimoto, S. Suzuki, and K. Ono, "Polylactic-acidpolyethylene glycol block copolymer: A new biodegradable synthetic carrier for bone morphogenetic protein," Clin. Orthop., 294, 333-343 (1993).

18. P. A. Lucas, C. Laurencin, G. T. Syftestad, A. Domb, V. M. Goldberg, A. I. Caplan, and R. Langer, "Ectopic induction of cartilage and bone by water-soluble proteins from bovine bone using a polyanhydride delivery vehicle," J. Biomed. Mater. Res., 24, 901-911 (1990).

19. M. Richards, B. I. Dahiyat, D. M. Arm, P. R. Brown, and K. W. Leong, "Evaluation of polyphosphates and polyphosphonates as degradable biomaterials," J. Biomed. Mater. Res., 25, 1151-1167 (1991).

20. O. N. Tretinnikov, K. Kato, and Y. Ikada, "In vitro hydroxyapatite deposition onto a film surface grafted with organophosphate film," J. Biomed. Mater. Res., 28, 13651373 (1994).

21. A. U. Daniels, K. P. Andriano, W. P. Smutz, M. K. O. Chang, and J. Heller, "Evaluation of absorbable poly(orthoesters) for use in surgical implants," J. Appl. Biomater., 5, 51-64 (1994).

22. C. T. Laurencin, M. E. Norman, H. M. Elgendy, S. F. El-Amin, S. Pucher, A. Ambrosio, and H. R. Alcock, "Polyphosphazenes-a novel biocompatible bioerodible polymer for bone regeneration," Trans. Orthop. Res. Soc., 18, 480 (1993).

23. S. I. Ertel and J. Kohn, "Evaluation of a series of tyrosinederived polycarbonates as degradable biomaterials," J. Biomed. Mater. Res., 28, 919-930 (1994).

24. O. Bostman, E. Hirvensalo, J. Makinen, and P. Rokkanen, "Foreign-body reactions to fracture fixation implants of biodegradable synthetic polymers," J. Bone J. Surg., 72B, 592-596 (1990). 
25. R. R. M. Bos, F. R. Rozema, G. Boering, A. J. Nijenhuis, A. J. Pennings, A. B. Verwey, P. Nieuwenhuis, and H. W. B. Jansen, "Degradation of and tissue reaction to biodegradable poly(l-lactide) for use as internal fixation of fractures: A study on rats," Biomaterials, 12, 32-36 (1991).

26. K. P. Andriano, T. Pohjonen, and P. Tormala, "Processing and characterization of absorbable polylactide polymers for use in surgical implants," J. Appl. Biomater., 5, 133-140 (1994).

27. W. K. Ramp, L. G. Lenz, and K. K. Kaysinger, “Medium $\mathrm{pH}$ modulates matrix, mineral, and energy metabolism in cultured chick bones and osteoblast-like cells," Bone and Mineral, 24, 59-73 (1994).

28. H. C. Blair, S. L. Teitelbaum, L. E. Grosso, D. L. Lacey, H. L. Tan, D. W. McCourt, and J. J. Jeffrey, "Extracellular-matrix degradation at acid $\mathrm{pH}, "$ Biochem. J., 290, 873-884 (1993).

29. A. A. Rezende, J. M. Pizauro, P. Ciancaglini, and F. A. Leone, "Phosphodiesterase activity is a novel property of alkaline phosphatase from osseous plate," Biochem. J., 301, 517-522 (1994).

30. G. Das and A. D. Hamilton, "Molecular recognition of carbohydrates: Strong binding of alkyl glycosides by phosphonate derivatives," J. Am. Chem. Soc., 116, 1113911140 (1994).

31. M. Richards, B. I. Dahiyat, D. M. Arm, S. Lin, and K. W. Leong, "Interfacial polycondensation and characterization of polyphosphates and polyphosphonates," J. Polym. Sci. Polym. Chem., 29, 1157-1165 (1991).

32. S. Banerjee, S. K. Palit, and S. Maiti, "Phosphorus containing polymers. Part 5. polyazooxyphosphonate," Coll. Polymer Sci., 272, 1203-1207 (1994).

33. L. C. Thomas, Interpretation of the IR Spectra of Organophosphorus Compounds, Heyden, London, 1974, pp. 56-71.

34. E. Griffith, Topics in Phosphorus Chemistry, Vol. III, Wiley, New York, 1966, pp. 56-73.
35. A. C. Hengge, W. A. Edens, and H. Elsing, "Transition state structures for phosphoryltransfer reactions of $\mathrm{p}$ nitrophenol phosphate," J. Am. Chem. Soc., 116, 50455049 (1994).

36. E. Tarelli and S. F. Wheeler, "Drying from phosphatebuffered solutions can result in the phosphorylation of primary and secondary alcohol groups of saccharides, hydroxylated amino acids, proteins, and glycoproteins," Anal. Biochem., 222, 196-203 (1994).

37. G. K. Hunter, C. L. Kyle, and H. A. Goldberg, "Modulation of crystal formation by bone phosphoproteins: Structural specificity of the osteopontin-mediated inhibition of hydroxyapatite formation," Biochem. J., 300, 723-728 (1994).

38. J. P. Glusker, "Structural aspects of metal liganding to functional groups in proteins," Adv. Protein Chem., 42, 1-76 (1991).

39. M. J. Gorbunoff, "The interaction of proteins with hydroxyapatite. II. Role of acidic and basic groups," Anal. Biochem., 136, 425-432 (1984).

40. C. T. Hanks, M. L. Diehl, R. G. Craig, P.-L. Makinen, and D. H. Pashley, "Characterization of the "in vitro pulp chamber' using the cytotoxicity of phenol," J. Oral Pathol. Med., 18, 97-107 (1989).

41. C. T. Hanks, S. E. Strawn, J. C. Wataha, and R. G. Craig, "Cytotoxic effects of resin components on cultured mammalian fibroblasts," J. Dent. Res., 70, 1450-1455 (1991).

42. G. Kozam and G. M. Mantell, "The effect of eugenol on oral mucous membranes," J. Dent. Res., 57, 954-957 (1978).

43. L. Lindqvist and P. Otteskog, "Eugenol: Liberation from dental materials and effect on human diploid fibroblast cells," Scand. J. Dent. Res., 89, 552-556 (1981).

44. W. R. Hume, "Effect of eugenol on respiration and division in human pulp, mouse fibroblasts and liver cells in vitro," J. Dent. Res., 63, 1262-1265 (1984).

Received September 5, 1995

Accepted February 21, 1996 